\title{
DNA strand breaks in liver for four aliphatic epoxides in mice
}

\author{
A.K. Giri, E.A. Messerly, P.K. Chakraborty, B.H. Hooberman and J.E. Sinsheimer \\ College of Pharmacy, University of Michigan, Ann Arbor, MI 48109-I065 (U.S.A.)
}

(Received 28 July 1989)

(Revision received 8 February 1990)

(Accepted 14 May 1990)

Keywords: Aliphatic epoxides; Epoxide precursors; DNA strand breaks, in vivo; Chemical reactivity; (Mouse)

\section{Summary}

Four aliphatic epoxides, 1-naphthyl glycidyl ether (NGE), 1-naphthylpropylene oxide (NPO), 4nitrophenyl glycidyl ether (NPGE), 3,3,3-trichloropropylene oxide (TCPO) and two of their precursors, 1-allylnaphthalene (AN) and 3,3,3-trichloropropylene (TCP), were selected for DNA strand-break analysis in liver in vivo with mice. The four epoxides selected were among the most mutagenic aliphatic epoxides in our previous structure-mutagenicity studies with the Ames test and had been evaluated for their in vivo genotoxicity as measured by sister-chromatid exchange (SCE) and chromosome aberrations (CA). A significant increase in the percentage of unwound DNA was observed at a 4-h exposure time for all the compounds at high doses except for AN. TCPO, the least genotoxic compound in bone marrow, had the greatest liver toxicity after 1-h exposure while NGE showed the most toxicity after $6 \mathrm{~h}$. As might be expected from their corresponding epoxides, AN but not TCP exhibited significant SCE activity in the bone marrow of mice. This study reemphasizes the importance of evaluating the stability of direct-acting alkylating agents in comparing test results and in establishing the relative order of genotoxicity for such compounds.

Aliphatic epoxides are important laboratory and industrial rea? ts and can arise by metabolic activation of unsaturated compounds. Since they are useful alkylating agents, their in vitro mutagenicity and in vivo genotoxicity is of interest (Manson, 1980; Ehrenberg and Hussain, 1981). As part of our investigation of structure-genotoxicity relationships for such compounds, we have recently reported (Giri et al., 1989) on the genotoxicity to bone-marrow cells of mice of 4 epoxides,

Correspondence: Dr. J.E. Sinsheimer, College of Pharmacy, University of Michigan, Ann Arbor, MI 48109-1065 (U.S.A.). 1-naphthyl glycidyl ether (NGE), 1-naphthylpropylene oxide (NPO), 4-nitrophenyl glycidyl ether (NPGE) and 3,3,3-trichloropropylene oxide (TCPO). The purpose of that study was to compare the in vivo genotoxicity of the compounds, as detected by sister-chromatid exchange (SCE) and chromosome aberrations (CA), to their in vitro mutagenicity. These compounds were 4 of the most mutagenic aliphatic epoxides in the Ames test (Maron and Ames, 1983) we have tested to date (Neau et al., 1982; Djuric et al., 1986; Rosman et al., 1987, 1988). In these studies, while TCPO was the strongest alkylating agent and a potent mutagen in the preincubation version of the Ames test, the order of in vivo genotoxicity for 
$\mathrm{SCE}$ was $\mathrm{NGE}>\mathrm{NPO}>\mathrm{NPGE} \cong \mathrm{TCPO}>$ solvent control.

It is the purpose of the present investigation to add to the limited information as to the in vivo genotoxicity of aliphatic epoxides (Manson, 1980; Ehrenberg and Hussain, 1981; Hopkins, 1984) by determining whether genotoxicity to the liver of mice could be detected for the 4 test epoxides. Strand-break (SB) analysis based upon the rate of alkaline unwinding of DNA (Rydberg, 1975) with separation of single-stranded from doublestranded DNA by the phenolic extraction procedure of Morris and Shertzer (1985), is to be used to measure such liver toxicity. The formation of epoxides through the metabolic oxidation of their unsaturated precursors may be of even greater toxicological concern than direct exposure to the epoxide per se (Manson, 1980). Therefore, two such metabolic precursors, 3,3,3-trichloropropylene (TCP) and 1-allylnaphthalene (AN) are also included in the present study. These precursors are to be tested in vivo for SB in liver and SCE in bone-marrow cells.

\section{Materials and methods}

\section{Animals}

Male $\mathrm{CD}_{1}$ mice 12 weeks old, weighing 30-35 $\mathrm{g}$, were purchased from Charles River Breeding Laboratories (Wilmington, MA). They were kept 5 per cage with wood chip bedding, fed Chow (Purina) and water ad libitum and housed 4-5 days prior to the start of the experiment.

\section{Chemicals}

5-Bromodeoxyuridine (BrdU) tablets $(50 \mathrm{mg}$ each) were purchased from Boehringer Mannheim Biochemicals (Indianapolis, IN). Colchicine, 7,12dimethylbenz $[a$ anthracene (DMBA) and $N$-nitrosodimethylamine (NDMA) were purchased from Sigma Chemical Co. (St. Louis, MO) while dimethyl sulfoxide (DMSO), 4-(4-nitrobenzyl)pyridine (NBP) and 3,3,3-trichloropropylene oxide (TCPO) were obtained from Aldrich Chemical Co. (Milwaukee, WI). 4-Nitrophenyl glycidyl ether (NPGE) was obtained from Eastman (Rochester, NY) and purified by repeated recrystallization from ethanol. 1-Naphthyl glycidyl ether (NGE) (Rosman et al., 1988), 1-naphthylpropylene oxide
(NPO) and its precursor 1-allylnaphthalene (AN) (Rosman et al., 1987) were prepared in this laboratory as previously noted. 3,3,3-Trichloropropylene (TCP) was prepared by the procedure of Haszeldine (1953). These compounds were purified by distillation under reduced pressure and/or by silica gel column chromatography ( $10 \%$ methylene chloride in hexane) until $2 \mu 1$ of a $10 \%$ solution of the test compound showed a single spot on TLC (silica-GF plates; Analtech, Newark, DE; hexane- $\mathrm{CH}_{2} \mathrm{Cl}_{2}$ 7:3) under UV light or where applicable after alkylation of a 4-(4-nitrobenzyl)pyridine spray (Hammock et al., 1974).

\section{Half-life studies}

The relative half-lives of the epoxides were determined by a modification of the procedure of Norppa et al. (1981) in which $1.25 \mathrm{ml}$ of a $40 \mathrm{mM}$ solution of epoxide in DMSO was added to 3.75 $\mathrm{ml}$ of DMSO and $20 \mathrm{ml}$ phosphate buffer $(0.1 \mathrm{M}$, $\mathrm{pH}$ 7.4). The mixture was heated at $37^{\circ} \mathrm{C}$ and, except for TCPO, aliquots $(1 \mathrm{ml})$ were removed at the appropriate time points. These were added to a mixture of $0.3 \mathrm{ml}$ acetone and $1.7 \mathrm{ml}$ of a $3.33 \%$ solution of NBP in ethylene glycol. In the case of TCPO, $0.25-\mathrm{ml}$ aliquots diluted with $0.75 \mathrm{ml}$ of buffer were used for the NBP test. These colorimetric test solutions were heated for $20 \mathrm{~min}$ at $37^{\circ} \mathrm{C}$, placed in a dry ice-acetone bath for $30 \mathrm{sec}$ and $2.0 \mathrm{ml}$ of triethylamine : acetone $(1: 1)$ added. The absorbance at $560 \mathrm{~nm}$ was read after $3 \mathrm{~min}$.

\section{In vivo DNA strand breaks in liver}

All test chemicals were dissolved in DMSO and were administered as a single intraperitoneal (i.p.) injection with the exposure times and doses noted in Table 1. Because of the non-polar nature of the compounds, DMSO $(75 \mu \mathrm{l})$ was used as the solvent for their i.p. administration as suggested by Preston et al. (1987) for other in vivo genotoxicity testing. Negative control mice were injected with $75 \mu 1$ of DMSO while NDMA was used as a positive control (Morris and Shertzer, 1985).

After the 1-, 4- or 6-h periods following chemical injection, animals were sacrificed by cervical dislocation and their livers immediately removed and rinsed in an ice-cold solution of $150 \mathrm{mM}$ $\mathrm{NaCl}$ and $1.0 \mathrm{mM} \mathrm{Na}{ }_{2}$ EDTA. Suspensions of liver cells were prepared following the squash 
method of Cox et al. (1973) from whole livers $(1.8-2 \mathrm{~g})$ in $5 \mathrm{ml}$ of the cold $\mathrm{NaCl}-\mathrm{Na}_{2}$ EDTA solution. The liver-cell suspensions were processed,
1.5- $\mathrm{ml}$ aliquots treated with $1.5 \mathrm{ml}$ of base, neutralized after $140 \mathrm{~min}$ with $1.5 \mathrm{ml}$ of $\mathrm{NaH}_{2} \mathrm{PO}_{4}$ solution, sonicated and extracted as described by

TABLE 1

ANALYSIS OF DNA STRAND BREAKS FOR 4 ALIPHATIC EPOXIDES AND 2 OF THEIR PRECURSORS IN VIVO IN MICE

\begin{tabular}{|c|c|c|c|c|}
\hline \multirow{2}{*}{\multicolumn{2}{|c|}{ Treatments (mg/kg) }} & \multicolumn{3}{|c|}{$\%$ of unwound DNA in different time intervals after treatment (mean \pm S.D. $)^{a}$} \\
\hline & & $\overline{6 h}$ & $4 \mathrm{~h}$ & $1 \mathrm{~h}$ \\
\hline Negativ & MSO) & $18.22 \pm 3.19$ & $16.68 \pm 3.41$ & $18.81 \pm 3.19$ \\
\hline NGE & $\begin{array}{r}50 \\
100 \\
200 \\
300 \\
600\end{array}$ & $\begin{array}{l}22.23 \pm 2.86 \\
25.33 \pm 2.99 * * \\
26.12 \pm 3.11 * *\end{array}$ & $\begin{array}{l}19.55 \pm 539 \\
20.78 \pm 5.52 \\
20.88 \pm 6.22 \\
25.76 \pm 2.22 *\end{array}$ & $\begin{array}{l}20.83 \pm 3.53 \\
20.54 \pm 2.68\end{array}$ \\
\hline TCPO & $\begin{array}{l}100 \\
200 \\
250 \\
300 \\
600\end{array}$ & $23.11 \pm 4.50$ & $\begin{array}{l}16.91 \pm 3.88 \\
24.01 \pm 7.92 * \\
24.69 \pm 3.53^{*}\end{array}$ & $\begin{array}{l}21.14 \pm 5.97 \\
35.14 \pm 3.53 * *\end{array}$ \\
\hline NPO & $\begin{array}{r}50 \\
100 \\
200 \\
300 \\
600\end{array}$ & $\begin{array}{l}20.17 \pm 3.82 \\
19.25 \pm 3.06 \\
24.70 \pm 4.41 *\end{array}$ & $\begin{array}{l}19.85 \pm 5.11 \\
20.33 \pm 3.57 \\
20.53 \pm 5.64 \\
23.41 \pm 2.56 *\end{array}$ & \\
\hline NPGE & $\begin{array}{l}100 \\
200 \\
300 \\
600\end{array}$ & $19.01 \pm 3.80$ & $\begin{array}{l}16.09 \pm 2.76 \\
20.45 \pm 4.15 \\
22.62 \pm 3.90^{*} \\
23.16 \pm 4.53 *\end{array}$ & \\
\hline AN & $\begin{array}{l}100 \\
200 \\
300 \\
600\end{array}$ & $19.66 \pm 2.05$ & $\begin{array}{l}18.59 \pm 3.57 \\
19.95 \pm 3.47 \\
19.63 \pm 3.98 \\
21.38 \pm 3.51\end{array}$ & \\
\hline TCP & $\begin{array}{l}100 \\
200 \\
300\end{array}$ & $19.23 \pm 3.80$ & $\begin{array}{l}19.72 \pm 4.40 \\
19.85 \pm 5.01 \\
24.01 \pm 3.99 *\end{array}$ & \\
\hline Positive & $\begin{array}{l}\text { MA) } \\
2.5 \\
5 \\
10 \\
20\end{array}$ & & $\begin{array}{l}25.99 \pm 4.55 \\
37.31 \pm 4.49 * * \\
43.18 \pm 6.89 * * \\
54.24 \pm 10.20 * *\end{array}$ & \\
\hline
\end{tabular}

\footnotetext{
ach value is the mean \pm S.D. of 5 animals. Results at each concentration were compared to those of the control using Dunnett's test $\left(* p<0.05\right.$ and $\left.{ }^{* *} p<0.01\right)$.
} 
Morris and Shertzer (1985). 5 animals were used for each concentration and 2 samples from each liver homogenate were analyzed. Total and double-stranded DNA were analyzed by the DNAspecific fluorometric dye (33258 Hoechst) method as described by Cesarone et al. (1979) and Daniel et al. (1985). Fluorescence was determined with a Perkin Elmer model LS-5 spectrophotometer with excitation at $350 \mathrm{~nm}$ and emission recorded at 454 $\mathrm{nm}$. Alkaline unwinding of DNA was calculated where the percentage of unwound DNA $=$ (total DNA - double-stranded DNA)/(total DNA) $\times$ 100.

\section{In vivo sister-chromatid exchange assay}

Paraffin-coated BrdU tablets (50 mg), following the methodologies of McFee et al. (1983) and Sharief et al. (1986), were used for in vivo SCE studies and cell replication kinetics analyses. Approx. $80 \%$ of the surface of the tablets was coated with embedding paraffin and the tablet implanted subcutaneously on the flank of mice under ether anesthesia. AN and TCP were administered as a single i.p. injection $30 \mathrm{~min}$ after tablet implantation. 5 doses $(10,25,50,100$ and $200 \mathrm{mg} / \mathrm{kg})$ for AN and 4 doses $(10,25,50$ and $100 \mathrm{mg} / \mathrm{kg})$ for TCP in $75 \mu 1$ of DMSO were used as determined from preliminary range-finding experiments. 5 animals were used for each concentration. Negative control mice were injected with $75 \mu \mathrm{l}$ of DMSO while DMBA was used as a positive control at a dose of $50 \mathrm{mg} / \mathrm{kg}$ body weight (Preston, 1987). Colchicine (4 mg/ $\mathrm{kg}$ ) was injected (i.p.) 22 $\mathrm{h}$ after the BrdU tablet implantation and $2 \mathrm{~h}$ later, bone marrow was expelled with $0.075 \mathrm{M} \mathrm{KCl}$. After hypotonic treatment $(0.075 \mathrm{M} \mathrm{KCl})$ for 20 min, cells were fixed 3 times with methanol-acetic acid $(3: 1)$. The slides were prepared and chromosomes were differentially stained (fluorescence-plus-Giemsa technique) in accordance with standard cytogenetic methods (Perry and Wolff, 1974; Latt et al., 1981; Giri et al., 1987). All the slides were coded and observed by a single observer. 30 second-division cells $(40 \pm 2$ chromosomes) per animal were scored for SCE frequencies, i.e. a total of 150 cells were scored per concentration tested. Randomly selected metaphase cells (200/animal) were scored for cell-replication kinetic analyses by their staining patterns as first $\left(M_{1}\right)$, second $\left(M_{2}\right)$ and third $\left(M_{3}\right)$ division metaphases. The replicative indices $(R I)$ were calculated as follows: $R I=\left(1 M_{1}+2 M_{2}+\right.$ $3 M_{3}$ )/200 (Krishna et al., 1985).

\section{Statistical analysis}

Dunnett's control group comparison test (onesided) was used for all chemicals to compare strand breaks and SCE with their respective negative controls, except with TCP for SCE, while the two-sided test was used for the $R I$ comparisons. Because of unequal sample sizes due to animal deaths for the TCP series in SCE, Tukey's test was used to make these comparisons of test results with their respective negative controls (Dunnett, 1980). The trend test method of Margolin et al. (1986), based upon the square root of the dose as the independent variable, was used for SB and SCE data with modification of eqn. 7 to facilitate the computation of standard errors and comparisons between compounds. Linear (NPO, NGE) and non-linear exponential (TCPO, NPGE) regression analyses were performed to determine best-fit models for the calculation of half-lives using the SYSTAT statistical package.

\section{Results and discussion}

Table 1 shows the results for SB analysis after i.p. exposure to NGE, NPO, NPGE and TCPO as well as two of their precursors TCP and AN, while Table 2 summarizes the trend tests for these chemicals. As several investigators have reported that

TABLE 2

TREND TEST FOR STRAND-BREAK ANALYSIS AND COMPARISON BETWEEN CHEMICALS

\begin{tabular}{lll}
\hline $\begin{array}{l}\text { Com- } \\
\text { pounds }\end{array}$ & $\begin{array}{l}\text { Trend } \pm \text { S.E. }^{\text {a }} \\
\text { (4-h treatment) }\end{array}$ & $\begin{array}{l}\text { Trend } \pm \text { S.E. }^{\text {a }} \\
(1-h \text { treatment })\end{array}$ \\
\hline NGE & $0.003478 \pm 0.001097 * *$ & $0.000791 \pm 0.001447$ \\
TCPO & $0.005111 \pm 0.001621 * *$ & $0.005682 \pm 0.001447 * * b$ \\
NPO & $0.002585 \pm 0.001096^{*}$ & \\
NPGE & $0.003131 \pm 0.001097 * *$ & \\
AN & $0.001397 \pm 0.001096$ & \\
TCP & $0.003635 \pm 0.001527 *$ & \\
\hline
\end{tabular}

a Trend tests are based upon percentages of unwound DNA vs. square root of dose.

b The difference in trend tests of TCPO-NGE after 1-h treatment was $0.004892 \pm 0.001274 * *$.

Tests were significant at ${ }^{*} p<0.05$ and ${ }^{* *} p<0.01$. 
NDMA is a potent inducer for SB (Parodi et al., 1981, 1983; Storer and Conolly, 1984; Morris and Shertzer, 1985), it was used as the positive control in the present study. Except for the lowest concentration, a significant increase in the percentage of unwound DNA was observed at all concentrations tested for NDMA with results which are very similar to those reported by Morris and Shertzer (1985). Initially, a 4-h exposure time with doses from 100 to $600 \mathrm{mg} / \mathrm{kg}$ was selected for SB analysis. In the case of TCPO and its metabolic precursor, TCP, acute toxicity to the mice limited their highest doses to 250 and $300 \mathrm{mg} / \mathrm{kg}$, respectively, for this time period. As noted in Table 2, significant dose-response effects were observed in the trend tests for all the compounds except AN. The only significant difference in the trend tests for the epoxides was for TCPO over NGE at $1 \mathrm{~h}$.

A 6-h exposure time was also selected to test whether we could increase the sensitivity of the SB test for any of the compounds. A dose of 200 $\mathrm{mg} / \mathrm{kg}$ was tested for all compounds. Only for those compounds where there were significant differences over the 6-h control values, were further tests conducted at 100 and $50 \mathrm{mg} / \mathrm{kg}$. A comparison of the 4-h results to those at $6 \mathrm{~h}$ shows that only the two compounds with the greatest chemical stability, NGE and NPO, exhibited greater genotoxicity with the extended exposure time. These two compounds were also the most genotoxic in our previous in vivo bone-marrow SCE study (Giri et al., 1989) and NGE, the most genotoxic epoxide in the previous study, also shows the greatest increase for SB with the increase in exposure time to $6 \mathrm{~h}$.

The differences in SB results as related to their time of exposure prompted us to determine the relative half-lives of our epoxides in predominately aqueous media. Norppa et al. (1981) have suggested that the shorter half-life of TCPO in relation to 3 other epoxides could be a factor in explaining why TCPO, with its high chemical alkylating ability, exhibited only relatively low results in their in vitro $\mathrm{CA}$ and SCE study with cultured human lymphocytes. In the present investigation, we have measured the hydrolysis rates of our epoxides by a modification of the procedure of Norppa et al. (1981) and the results for this comparison are shown in Fig. 1. The NBP ab-

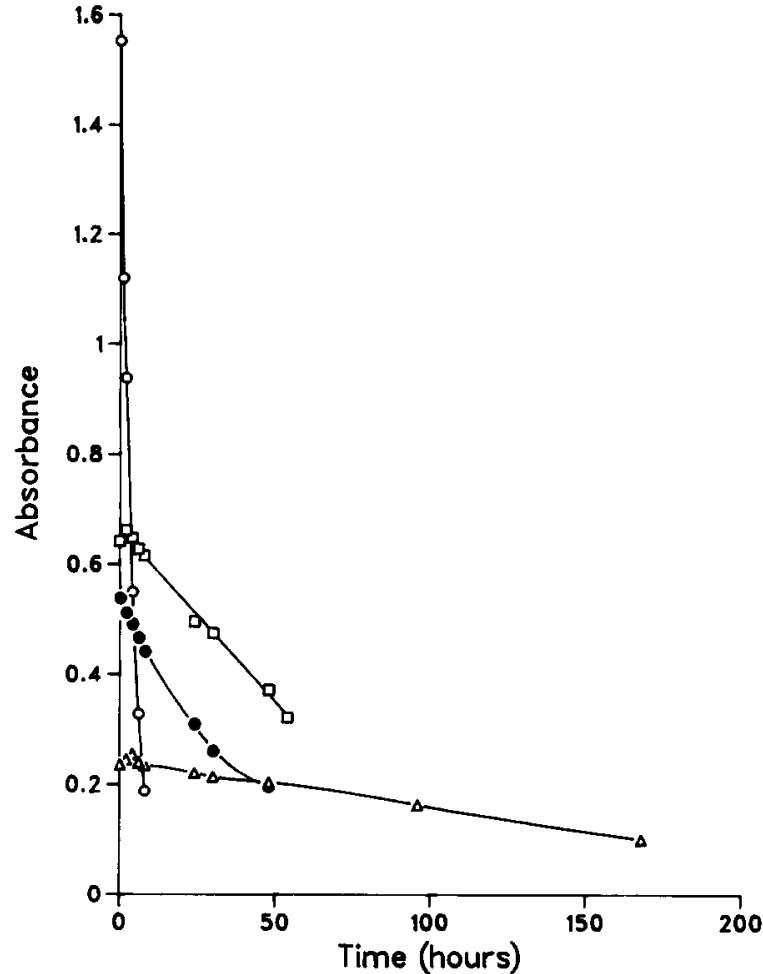

Fig. 1. Stability at $37^{\circ} \mathrm{C}$ of the epoxides (40 mM) in DMSOphosphate buffer ( $\mathrm{pH} 7.4$ ) as measured by the absorbance of the remaining epoxide in the NBP test. The aliquots used to measure remaining epoxide for TCPO was a fourth of that used for the other epoxides. $\Delta, 1$-naphthylpropylene oxide; $\square$, 1-naphthyl glycidyl ether; $\bullet$, 4-nitrophenyl glycidyl ether; $O$, trichloropropylene oxide.

sorbances at the zero-time aliquots, adjusted for the dilution of TCPO, are an indication of the relative strength of the epoxides as alkylating agents. These absorbances together with the halflife values of the epoxides are: TCPO $(6.212 ; 2.7$ h), NGE (0.642; 55 h), NPGE (0.538; 30 h), NPO $(0.236 ; 122 \mathrm{~h})$. Under our experimental conditions, TCPO had a shorter half-life than previously reported by Norppa et al. (1981). However, in the present study lower concentrations of epoxides were used in more aqueous media with a change of buffers at a higher concentration and somewhat higher $\mathrm{pH}$ (7.4). Both investigations demonstrate that TCPO is a much stronger alkylating agent and is considerably less stable than the other epoxides studied. 
The shorter half-life of TCPO together with its increased activity as an alkylating agent but with its greater acute toxicity induced us to compare its in vivo $\mathrm{SB}$ activity with liver cells to that of $\mathrm{NGE}$ with only 1-h exposure at 300 and $600 \mathrm{mg} / \mathrm{kg}$. These are doses of TCPO that kill mice within $4 \mathrm{~h}$. There was a statistically significant increase in SB at $600 \mathrm{mg} / \mathrm{kg}$ for TCPO but not for NGE and a significant difference in their trend tests $(P<0.01$, see Table 2) for the 2 compounds for this time period. This could be due to TCPO's greater strength as an alkylating agent but could only be demonstrated under conditions where TCPO's short half-life and high rate of detoxication would be compensated by high doses for a brief time to avoid a lethal effect. However, as noted by Nelson and Bull (1988) in their study of the induction of SB by trichloroethylene, SB results may include DNA effects by mechanisms other than by direct DNA alkylation. Thus, in the present investigation where some doses were extended to the limit of toxicity of the epoxides, SB effects could be secondary to cytotoxicity.

While TCP, the metabolic precursor of TCPO, produced statistically significant SB activity at the highest dose that could be tested for 4-h exposure (Table 1) and its dose-response trend test was significant, this was not true for $\mathrm{AN}$, the precursor for NPO. This led to an examination of the bonemarrow genotoxicity for the 2 precursors in the same manner we had reported for the epoxides (Giri et al., 1989). In the results of this testing as shown in Table 3, the reverse situation is true with a weak response $(5.22 \mathrm{SCE} /$ cell with $200 \mathrm{mg} / \mathrm{kg}$ ), being established for AN but not for TCP. This is in contrast to the expected strong response for the positive control DMBA (14.25 with $50 \mathrm{mg} / \mathrm{kg}$ ). The AN and TCP results are consistent with our previous report for their corresponding epoxides where NPO produced a greater SCE response than TCPO and could be consistent with the fact that the shorter half-life for TCPO as well as its high

TABLE 3

SISTER-CHROMATID EXCHANGE INDUCED BY 1-ALLYLNAPHTHALENE AND TRICHLOROPROPYLENE ON BONE-MARROW CELLS OF MICE

\begin{tabular}{|c|c|c|c|c|}
\hline Treatment & SCE /cell of 5 animals & $\begin{array}{l}\mathrm{SCE} / \text { cell } \\
(\text { mean } \pm \text { S.D. })^{\mathrm{a}}\end{array}$ & Trend \pm S.E. ${ }^{b}$ & $\begin{array}{l}\text { Replicative } \\
\text { index (RI) } \\
\text { (mean } \pm \text { S.D.) }\end{array}$ \\
\hline \multicolumn{4}{|c|}{ Solvent control } & $1.81 \pm 0.09$ \\
\hline \multicolumn{5}{|c|}{ AN (mg/kg) } \\
\hline 10 & $3.6,4.7,3.7,3.9,3.8$ & $3.93 \pm 0.44$ & & $1.89 \pm 0.11$ \\
\hline 25 & $4.4,3.9,4.0,4.7,3.6$ & $4.13 \pm 0.43$ & & $1.88 \pm 0.12$ \\
\hline 50 & $4.3,4.2,4.4,4.1,4.8$ & $4.38 \pm 0.28$ & $0.10990 \pm 0.0213 * *$ & $1.86 \pm 0.13$ \\
\hline 100 & $4.2,4.3,4.5,5.4,4.7$ & $4.60 \pm 0.47 *$ & & $1.86 \pm 0.12$ \\
\hline 200 & $4.6,5.2,4.4,7.1,4.8$ & $5.22 \pm 1.07 * *$ & & $1.87 \pm 0.10$ \\
\hline \multicolumn{5}{|c|}{$\mathrm{TCP}$ (mg/kg) } \\
\hline 10 & $3.3,3.3,3.7,3.8,4.5$ & $3.71 \pm 0.50$ & . & $1.85 \pm 0.12$ \\
\hline 25 & $4.8,4.5,3.9,3.6,3.6$ & $4.09 \pm 0.55$ & 10 & $1.86 \pm 0.13$ \\
\hline 50 & $4.1,4.3,3.8,4.9,4.0$ & $4.24 \pm 0.41$ & $0.05456 \pm 0.0330$ & $1.84 \pm 0.11$ \\
\hline $100^{\mathrm{c}}$ & $4.1,3.9,4.4,3.6$ & $4.01 \pm 0.34$ & & $1.84 \pm 0.12$ \\
\hline \multicolumn{5}{|c|}{ Positive control (DMBA) } \\
\hline $50 \mathrm{mg} / \mathrm{kg}$ & $14.5,15.3,13.1,15.5,12.8$ & $14.25 \pm 1.22$ & & $1.81 \pm 0.11$ \\
\hline
\end{tabular}

\footnotetext{
a Mean \pm S.D. for 5 animals ( 30 cells per animal). Results at each concentration were compared to those of the control using Dunnett's test, except for TCP where Tukey's test was used.

b Trend tests are based upon number of counts vs. square root of dose.

c 1 animal died at this concentration.

${ }^{*} p<0.05$ and ${ }^{* *} p<0.01$.
} 
rate of detoxication in the liver (Sinsheimer et al., 1987) do not permit high enough concentrations of the metabolically produced TCPO to accumulate in bone marrow.

While we have previously shown NGE, NPO, NPGE and TCPO to be genotoxic in vivo in the bone marrow of mice, TCPO was consistently among the least genotoxic of the epoxides. The contrast in the order of toxicity for TCPO in comparison to our SB results at the shorter time intervals might again be a function of the greater reactivity of TCPO in comparison to the other epoxides. I.p. administration was employed for both the bone marrow tests and for the current SB evaluation. Both polar and nonpolar xenobiotic compounds in the molecular weight range of the epoxides under study would be expected to be absorbed from the peritoneum via the portal system (Lukas et al., 1971) and reach the liver before bone marrow (Dedrick et al., 1978). Therefore, the relative concentrations of epoxides reaching the bone marrow in comparison to the liver could be a function of their chemical reactivities especially as influenced by detoxication in a first pass effect through the liver. Indeed we have previously shown that the extent of detoxication of epoxides in rat-liver homogenates could be related to their chemical reactivity (Sinsheimer et al., 1987) in which the role of the glutathione transferase system was especially important.

The present study adds to the limited examples of SB analyses for aliphatic epoxides. Solveig Walles and Orsen (1983) have reported that both styrene and styrene oxide can induce SB in various tissues. Such DNA breakage was also observed for germ cells after exposure to ethylene oxide using an alkaline elution technique (Sega and Generoso, 1988). The present study also serves to reemphasize the importance of the consideration of the half-lives of direct-acting alkylating agents in the evaluation of their in vivo genotoxicities. This may become particularly important in relating in vitro to in vivo genotoxicity tests and in comparing the relative order of a series of compounds with changes in the testing method or protocol. This is illustrated in the present study by the effect of exposure time of the epoxides on their liver SB results and by the reversal of the order of genotoxicity for TCPO in relationship to the other epoxides in SB compared to our former SCE analysis in bone marrow.

\section{Acknowledgements}

The authors express their appreciation to the Statistical Research Laboratory, University of Michigan, for their assistance in the analysis of our data. This investigation was supported by Grant R01 ES03345 from the National Institute of Environmental Health Sciences, DHHS.

\section{References}

Cesarone, C.F., C. Bolognesi and L. Santi (1979) Improved microfluorometric DNA determination in biological material using 33258 Hoechst, Anal. Biochem., 100, 188197.

Cox, R., I. Damjanov, S.E. Abanobi and D.S.R. Sarma (1973) A method for measuring DNA damage and repair in the liver in vivo, Cancer Res., 33, 2114-2121.

Daniel, F.B., D.L. Haas and S.M. Pyle (1985) Quantitation of chemically induced DNA strand breaks in human cells via alkaline unwinding assay, Anal. Biochem., 144, 390-402.

Dedrick, R.L., C.E. Myers, P.M. Bungay, and V.T. DeVita (1978) Pharmacokinetic rationale for peritoneal drug administration in the treatment of ovarian cancer, Cancer Treat. Rep. 62, 1-9.

Djuric, Z., B.H. Hooberman, L. Rosman and J.E. Sinsheimer (1986) Reactivity of mutagenic propylene oxides with deoxynucleosides and DNA, Environ. Mutagen., 8, 369-383.

Dunnett, C.W. (1980) Pair-wise multiple comparison in the homogeneous variance, unequal sample size case, J. Am. Stat. Assoc., 75, 789-795.

Ehrenberg, L., and S. Hussain (1981) Genetic toxicity of some important epoxides, Mutation Res., 86, 1-113.

Giri, A.K., T.S. Banerjee, G. Talukder and A. Sharma (1987) Induction of sister chromatid exchange and dominant lethal mutation by "Katha" (Catechu) in male mice, Cancer Lett., 36, 189-196.

Giri, A.K., E.A. Messerly and J.E. Sinsheimer (1989) Sisterchromatid exchange and chromosome aberrations analyses for 4 aliphatic epoxides in mice, Mutation Res., 224, 253261.

Hammock, L.G., B.D. Hammock and J.E. Casida (1974) Detection and analysis of epoxides with 4-( $p$-nitrobenzyl)pyridine, Bull. Environ. Contam. Toxicol., 12, 759-764.

Haszeldine, R.N. (1953) Fluoro-olefins, Part II: Synthesis and reactions of some $3: 3: 3$-trihalogenopropenes, J. Chem. Soc. (London), 3371-3378.

Hopkins, J. (1984) Genotoxicity and carcinogenicity of glycidyl ether, Food Chem. Toxicol., 22, 780-783.

Krishna, G., J. Xu, J. Nath, M. Petersen and T. Ong (1985) In vivo cytogenetic studies on mice exposed to ethylene dibromide, Mutation Res., 158, 81-87.

Latt, S.A., J. Allen, S.E. Bloom, A. Carrano, E. Falke, D. Kram, E. Schneider, R. Schreck, R. Tice, B. Whitfield and 
S. Wolff (1981) Sister-chromatid exchanges: A report of the Gene-Tox Program, Mutation Res., 87, 17-62.

Lukas, G., S.D. Brindle and P. Greengard (1971) The route of absorption of intraperitoneally administered compounds, J. Pharmacol. Exp. Ther., 178, 562-566.

Manson, M.M. (1980) Epoxides - is there a human health problem?, Br. J. Indust. Med., 37, 317-336.

Margolin, B.H., M.A. Resnick, J.Y. Rimpo, P. Archer, S.M. Galloway, A.D. Bloom and E. Zeiger (1986) Statistical analyses for in vitro cytogenetic assays using Chinese hamster ovary cells, Environ. Mutagen., 8, 183-204.

Maron, D.M., and B.N. Ames (1983) Revised methods for the Salmonella mutagenicity test, Mutation Res., 113, 173-215.

McFee, A.F., K. Lowe and J.R. San Sebastian (1983) Improved sister chromatid differentiation using paraffin-coated bromodeoxyuridine tablets in mice, Mutation Res., 119, 83-88.

Morris, S.R., and H.G. Shertzer (1985) Rapid analysis of DNA strand breaks in soft tissues, Environ. Mutagen., 7, 871-880.

Neau, S.H., B.H. Hooberman, S.W. Frantz and J.E. Sinsheimer (1982) Substituent effects on the mutagenicity of phenyl glycidyl ethers in Salmonella typhimurium, Mutation Res., 93, 297-304.

Nelson, M.A., and B.J. Bull (1988) Induction of strand breaks in DNA by trichloroethylene and metabolites in rat and mouse liver in vivo, Toxicol. Appl. Pharmacol., 94, 45-54.

Norppa, H., K. Hemminki, M. Sorsa and H. Vainio (1981) Effect of monosubstituted epoxides on chromosome aberrations and SCE in cultured human lymphocytes, Mutation Res., 91, 243-250.

Parodi, S., P. Carlo, A. Martelli, M. Taningher, R. Finollo, M. Pala and W. Giaretti (1981) A circular channel crucible oscillating viscometer, Detection of DNA damage induced in vivo by exceedingly small doses of dimethylnitrosamine, J. Mol. Biol., 147, 501-521.

Parodi, S., C. Balbi, M.L. Abelmoschi, M. Pala, P. Russo and L. Santi (1983) Studies on DNA damage: Discordant responses of rate of DNA disentanglement (viscometrically evaluated) and alkaline elution rate, obtained for several compounds. Possible explanations of the discrepancies, Cell Biophys., 5, 285-300.

Perry, P., and S. Wolff (1974) New Giemsa method for the differential staining of sister chromatids, Nature (London), 251, 156-158.

Preston, R.J., B.J. Dean, S. Galloway, H. Holden, A.F. McFee and M. Shelby (1987) Mammalian in vivo cytogenetic assays, Analysis of chromosome aberrations in bone marrow cells, Mutation Res., 189, 157-165.

Rosman, L.B., V. Gaddamidi and J.E. Sinsheimer (1987) Mutagenicity of aryl propylene and butylene oxides with Salmonella, Mutation Res., 189, 189-204.

Rosman, L.B., P.K. Chakraborty, E.A. Messerly and J.E. Sinsheimer (1988) Mutagenicity of aromatic glycidyl ethers with Salmonella, Mutation Res., 206, 115-125.

Rydberg, B. (1975) The rate of strand separation in alkali of DNA of irradiated mammalian cells, Radiat. Res., 61, 274-287.

Sega, G.A., and E.E. Generoso (1988) Measurement of DNA breakage in spermiogenic germ-cell stages of mice exposed to ethylene oxide, using an alkaline elution procedure, Mutation Res., 197, 93-99.

Sharief, Y., A.M. Brown, L.C. Backer, J.A. Campbell, B. Westbrook-Collins, A.G. Stead and J.W. Allen (1986) Sister chromatid exchange and chromosome aberration analyses in mice after in vivo exposure to acrylonitrile, styrene, or butadiene monoxide, Environ. Mutagen., 8, 439-448.

Sinsheimer, J.E., E. Van den Eeckhout, B.H. Hooberman and V.G. Beylin (1987) Detoxication of aliphatic epoxides by diol formation and glutathione conjugation, Chem.-Biol. Interact., 63, 75-90.

Solveig Walles, S.A., and I. Orsen (1983) Single-strand breaks in DNA of various organs of mice induced by styrene and styrene oxide, Cancer Lett., 21, 9-15.

Storer, R.D., and R.B. Conolly (1984) An in vivo-in vitro alkaline DNA unwinding assay for hepatic DNA damage: Comparison with the alkaline sucrose gradient centrifugation technique, Anal. Biochem., 142, 351-359. 